\title{
Nevoluntární hledání života
}

\section{Jiří Olšovský}

\section{Envigogika 12 (2) - Inspirace/ Inspiration}

Publikováno / Published 27. 11. 2017

DOI: $\underline{10.14712 / 18023061.551}$

\begin{abstract}
Abstrakt
Žijeme $v$ době, kdy antropogenní procesy mohou vést $\mathrm{k}$ úplné devastaci života na Zemi. Je proto správné přemýšlet o tom - šlo by klimatickou změnu ovlivnit pozitivně? Podle autora je k tomu zapotřebí dosáhnout obratu v myšlení, zásadně pochopit environmentální problémy, a následně pak změnit politicko-ekonomické procesy, zharmonizovat lidskou činnost s prírodními cykly - to ale nejde udělat s využitím starých znalostí. Nutné je pracovat především s nejnovějšími vědeckými poznatky o změně klimatu, o zamořování půdy, vody, atmosféry - slepota vůči těmto informacím je zjevně poháněna dogmaticko-ideologickými důvody. Znalost základních fakt o problémech světa rovná se (environmentální) vzdělanost, kterou pak potřebují především politici, aby nezůstali uzavřeni ve svém krátkozrakém, pohodlném a líbivém rozhodování. Pochopení širších souvislostí však vyžaduje "skok v myšlení", odvahu opustit rigidní, zakonzervované názory. Možná jde o proměnu racionality jako takové - přechod od hyperracionalistického panství nad př́rodou směrem k vnímavému, empatickému porozumění bytí a reality. Ono panství se z dnešní perspektivy jeví jako predátorská, kalkulativně vytěžující ideologie, kterou se člověk staví proti sobě samému, zapomínaje na své pravé lidství.
\end{abstract}

\section{Klíčová slova}

klimatická změna; obrat v myšlení; vzdělání

\begin{abstract}
We live at a time when anthropogenic processes can lead to the complete devastation of life on Earth. Is it necessary to think - how the climate change could be affected positively? According to the author, it is necessary to achieve a turning point in thinking, to reach fundamental understanding of the environmental problems, and subsequently to change political-economic processes, to harmonize human activity with natural cycles - but this cannot be done with our old awareness. First and foremost, the latest scientific knowledge of climate change, soil pollution, water, atmosphere is needed - the "blindness" neglecting this information is obviously driven by dogmatic and ideological reasons. Knowledge about the basic facts concerning the most pressing world's problems is, in fact, basic (environmental) education that politicians need in the first place not to stay in their shortsighted, comfortable and appealing decisions. Understanding of wider contexts, however, requires a
\end{abstract}


"jump in thinking", the courage to leave rigid, conservative views. Perhaps it is a transformation of rationality as such - the transition from the hyper-ratiocinative dominance over nature to the perceptual, empathic understanding of being and reality. The first one, from today's perspective, appears to be a predatory, calculatively exploiting ideology that is against true humanity.

\section{Keywords}

climate change; transition; education

Žijeme ve světě, ve kterém se stále mohutně plýtvá zdroji (např. zásobami vody, ropy, dřeva). Zvrátit antropogenní proces vedoucí k úplné devastaci Země bude jistě těžký úkol. Je proto určitě správné podporovat každou rozumnou iniciativu, která povede k zažehnutí možného obratu $v$ chápání environmentálních problémů, což by mohlo vést $k$ záchraně života na Zemi. Cestou k tomu je zmenšení devastace životního prostředí, ozdravení prírody. Zatím ovšem vidíme po celém světě stále rưst arogantního dobývání a ničení planety, což se projevuje např. v zamořování oceánů plasty, jež se jen velmi pomalu rozkládají - a když se už rozloží, polykají zbytky této plastické hmoty ryby, prostřednictvím nichž se pak dostávají i do člověka.

Jak pokračuje dál jiné plundrování světa? Třeba v Thajsku se ničí mangrovníky kvưli produkci krevet pro vývoz (nejde jen o vlastní spotřebu), v Indonésii probíhá podobně rozsáhlé odlesňování kvůli pěstování palem pro palmový olej, opět zejména pro vývoz. Je třeba s tím vším skončit a nastartovat méně antropocentrický a zběsile-profitový prístup ke světu, což by politici všech úrovní konečně mohli začít chápat, a to vzhledem $\mathrm{k}$ tomu, $\mathrm{s}$ jakými nevídanými jevy se dnes setkáváme, že se již zdá, že sám oceán a sama země se začínají bránit. Prostředí vhodné pro život člověka i všech rostlin a živočichů se vyvíjelo milióny a miliardy let, a je proto nezbytné $v$ zájmu zachování života na Zemi (jestliže i člověk chce ještě existovat tisíce let spolu s ostatním živočichy, třeba se Ivy, tygry, žraloky, slony, zpěvnými ptáky, ovšem i se stromy a rostlinami), aby došlo $\mathrm{k}$ radikální změně v lidském myšlení i konání. Bude nutno probudit ve všech lidech autenticky nevoluntární étos (zvláště v politicích s největší odpovědností), aby se prosadila větší ohleduplnost $k$ prírodě a zemi, aby se $v$ člověku vzbudila větší pokora před tajemstvím bytí a života. Jedině tak se udrží příznivé podmínky k životu, zajistí se prostor k naplnění existence každého jednotlivce; člověk bude obdařen novou chutí žít, zbaven zátěže plundrujícího nihilismu.

\section{Nová politika}

A tak i na pozitivní klimatickou změnu je zjevně zapotřebí zapůsobit pozitivně, a to nejlépe tak, že nahlédneme ony procesy, zvláště politicko-ekonomické, jež jsou poháněny nenasytnou ziskovostí a jež vposledku vedou $\mathrm{k}$ devastaci země, k zamořování moří a ovzduší celé zeměkoule, $k$ popírání světa $v$ jeho původnosti. Na proměně klimatu se nepochybně spolupodílí i činnost člověka - jeho zatím ne přiliš ekologická ekonomika a přebujelý neregulovaný neoliberalismus. Jiná cesta než lépe zharmonizovat lidskou činnost s prírodními cykly a kosmickými procesy není. Ekonomické pohyby však může korigovat jen náležitě vyspělá politika, politikové by tudíž $v$ žádném případě neměli být ve vleku nenasytných ekonomických struktur a finančního kapitálu, jimž jde jenom o megazisk (potřebný nejspíš pro 
svůj přiští úprk do nějakého méně vysátého a méně zničeného místa - pokud se ještě nějaké takové místo bude na zeměkouli vyskytovat).

K pohybu pozitivní změny je nutno co nejrychleji dospět, vzít $v$ úvahu současné vědecké poznatky o změně klimatu, o zamořování půdy, vody, atmosféry. Nelze se obracet ke starým poznatkům meteorologů, pro něž bylo obtížné před sto lety zachytit svými jednoduchými př́stroji proměny klimatu. Člověk způsobuje svou aktivitou zemi, ovzduší i oceánům evidentní šrámy, přirozený svět se mu rozkládá před očima, dusí se a musí žít v znečištěném životním prostředí. Dnes data, ze kterých Ize vyčíst stupně znečištění a různé devastace, jsou $\mathrm{k}$ dispozici a nevidí je jen ten, kdo je $z$ nějakých dogmaticko-ideologických důvodů nechce vidět. Pak se ale nevidí základní, vědeckými metodami zjištěný fakt zvyšování průměrné zemské teploty $v$ porovnání $s$ předindustriální dobou a $s$ tím související pozvolné stoupání hladiny a teploty všech oceánů světa v důsledku tání ledovců apod. Co to dělá se všemi obyvateli moří, je dobře známo - vymírají celé skupiny rostlin a živočichů. Cynický dogmatik pevně usazený ve svém dogmatu však nedohlédne dál než $\mathrm{k}$ tomu, co bude přriští den - představit si situaci na Zemi za padesát či sto let mu jaksi nejde, asi spoléhá na to, že vše vyřeší volná ruka trhu či ziskuchtivá globální oligarchie, nebo nás zachrání nějaký ten deus ex machina.

Náš životní svět se začíná otřásat, přelidnění jde ruku v ruce $s$ vyhlazováním zviřat, $s$ pozvolna "neviditelně" postupujícím oteplováním planety a vysušováním velkých doposud plodných území (snižují se zásoby podzemních vod), což je často spjato s bezohledným drancováním zbylých zdrojů, odlesňováním, novým a novým osidlováním, nespoutanou migrací apod. Lámou se teplotní rekordy, mohutný hurikán či tajfun a tornádo postupují jeden za druhým, ovšem popírači skleníkového efektu (s jeho vědecky dokázaným růstem množství vodní páry, oxidu uhličitého, metanu, oxidu dusného a dalších skleníkových plynů $v$ zemské atmosfére) dál lobbují za "krásný zářný" svět věčného růstu ekonomických parametrů, abychom se přece měli "dobře" i za cenu rostoucího ohrožení. Na různé známky blížících se katastrof a kolapsů se nehledí, vše zatím přece "ještě nějak jde", ale to, že vymírají živočichové a zanikají celé zóny života nikoho z ekonomistů a lenivých nevzdělaných politiků př́liš nezajímá. Důsledky antropogenní činnosti na biodiverzitu se nezohledňují nebo se stále bagatelizují.

\section{Skok v myšlení}

Pro pochopení dějů světa je zapotřebí především růst vzdělanosti, jak to doporučoval a sám realizoval např́klad Tomáš Garrigue Masaryk. Když viděl (jak se můžeme dnes domnívat), že se ještě potřebuje $v$ mnohém dovzdělat, opustil politiku, a teprve poté, co zjistil, že už je na patřičné výši vzdělanosti potřebné pro politiku, opět do ní vstoupil - je pro ni potřeba opravdu komplexní vzdělání, zbavené povrchnosti. Dnes jde samozřejmě o intenzivně poučené pochopení toho, že je nutno podporovat každou iniciativu, která vede $\mathrm{k}$ zastavení negativních trendů sužujících planetu Zemi, proto je zajisté dobré podpořit všechny rozumné úmluvy o klimatu a o životním prostředí a radikálně nastartovat rozvoj směrem $\mathrm{k}$ obnovitelným energetickým zdrojům, k obrozené a prohloubené péči o zemi a př́rodu. Pro mnohé politiky to znamená skok v myšlení: musí dospět $\mathrm{k}$ jistému druhu osvícení, vytrhnout se ze starých zajetých - často pouze mechanicky manipulativních - kolejí, což je samozřejmě velmi obtí̌né. Lze se však nakonec dostávat na vyšší úroveň cítění a myšlení, chce to "jen" najít v sobě odvahu opustit rigidní, ztuhle zakonzervované názory a přijmout zdravý zeleno-modrý (barva našich lesů, hor a strání, jak říkají básníci) konzervatismus zaměřený na obnovu a oživení harmoničtějšího vztahu $\mathrm{k}$ prírodním živlům a bytí vůbec. Dnes jde 0 samo ryzí nedualistické a nelineární pochopení běhu světa a věcí v něm, a každý politik a 
veřejně činný jednotlivec by se měl naučit chápat základní ontologii či filosofii světa, přibližovat se tak co nejvíce pravdě bytí - jak se opravdu věci dějí a mají dít. Tehdy i svět, v němž žijeme, bude autenticky "světovat", jak psal německý filosof a básník Martin Heidegger. Poté nám snad zasvítí i krásnější a existenciálnější možnosti pro náš domov, který se konečně zbaví tíživého hyperracionalistického panství nad prírodou; tehdy se věci "nechají být", aby se mohly uskutečňovat podle své přirozenosti. Pak i pohyby naší existence, jak uvažoval také český filosof Jan Patočka, budou opravdovější ve svém směřování $k$ vnímavějšímu porozumění bytí a reality, $\mathrm{k}$ lepší a ohleduplnější praxi $v$ zacházení se světem a prírodou.

Nový ekologičtěji-environmentální přístup ke světu půjde ruku $v$ ruce $s$ budoucím „jemnějším" kapitalismem, který bude znamenat nenihilistický a nelhostejný přístup k záležitostem a dějům ve společnosti a $v$ prírodě, prístup citlivě zohledňující možnosti dalšího života na planetě Zemi. Upadlý nihilista, ve smyslu pouhého nevzdělaného predátora, kterému jde jen o vlastní superprofit a pohodlí, se veze především po vině neustálého "růstu dobyvačného růstu", jenž sice přináši věčný tok dividend, prebend a nevídaných nadzisků, ale i druh pomsty na prírodě, kdy i člověk, jsoucí ve vleku kalkulativně vytěžujících ideologií, se staví proti sobě samému, zapomíná na své pravé lidství. Půjde nyní o to, zbavit se takové "Iví morálky", jak o to koneckonců usiloval i německý filosof a básník Friedrich Nietzsche. Predátorský postoj ještě znamená nenasytné vytěžování skutečnosti až do morku kostí, do poslední žíly kovu $v$ zemi, do posledního stromu v krajině, do posledního nosorožce pro jeho roh, do posledního tygra instinktivně kráčejícího krajinou po své přirozené cestě. Vydat se stezkou změny přístupu k životnímu prostředí a k životu vůbec, o to dnes jde - a tedy radikálně se začít prolamovat $\mathrm{k}$ době, kdy například spalovací motory přestanou převažovat (nastoupí co nejdřive zejména elektrický a vodíkový pohon), kdy se do ovzduší bude vypouštět minimum skleníkových plynů - ty do sebe pojme ekosystém Země, přirozeně rostoucí lesy a pralesy. Tehdy zmizí i "fosilní průmysl", a dojde tedy k výrazné dekarbonizaci světa. Pak zas vskutku začneme chápat posvátné součtveří světa a ryzí pravdu bytí (viz k tomu blíže např. knížku Stezkou proměny, Malvern, 2017). 